\title{
Arsenic disulfide induces apoptosis of human diffuse large B cell lymphoma cells involving Bax cleavage
}

\author{
LING WANG ${ }^{1,2}$, XINYU LIU ${ }^{1}$, XIANGLU LI ${ }^{1}$, XIAO LV ${ }^{1}$, KANG LU $^{1}$, \\ NACHEN ${ }^{1}$, PEIPEI LI $^{1}$ and XIN WANG ${ }^{1,3}$ \\ ${ }^{1}$ Department of Hematology, Provincial Hospital Affiliated to Shandong University, Jinan, Shandong 250021; \\ ${ }^{2}$ Department of Hematology, Taian City Central Hospital, Taian, Shandong 271000; \\ ${ }^{3}$ Institute of Diagnostics, Shandong University, Jinan, Shandong 250012, P.R. China
}

Received July 18, 2013; Accepted August 23, 2013

DOI: $10.3892 /$ or.2013.2729

\begin{abstract}
The aim of the present study was to investigate the effect of arsenic disulfide $\left(\mathrm{As}_{2} \mathrm{~S}_{2}\right)$ on the proliferation and apoptosis of LY1 and LY8 human diffuse large B cell lymphoma (DLBCL) cells in an attempt to discover a more effective alternative therapy scheme. Human DLBCL cells LY1 and LY8 were treated with various concentrations of $\mathrm{As}_{2} \mathrm{~S}_{2}$ for different time periods. Cell viability was detected by the CCK-8 assay; cell apoptosis was evaluated by flow cytometric analysis. The expression levels of Bax, Bcl-2 and caspase-3 were examined by quantitative PCR and western blotting. We found that the DLBCL cell viability was significantly decreased following treatment with $\mathrm{As}_{2} \mathrm{~S}_{2}$ for 24, 48 and $72 \mathrm{~h}$. Along with increasing $\mathrm{As}_{2} \mathrm{~S}_{2}$ concentrations, the DLBCL cell viability was notably reduced when compared with the control group, and the results were statistically significant. Meanwhile, the apoptotic rates of DLBCL cells were significantly enhanced at 24,48 and $72 \mathrm{~h}$ following treatment with
\end{abstract}

Correspondence to: Professor Xin Wang, Department of Hematology, Provincial Hospital Affiliated to Shandong University, No. 324 Jingwu Road, Jinan, Shandong 250021, P.R. China

E-mail: xinw@sdu.edu.cn

Abbreviations: NHL, non-Hodgkin lymphoma; DLBCL, diffuse large B cell lymphoma; HDT, high-dose therapy; ASCT, autologous stem cell transplantation; $\mathrm{As}_{2} \mathrm{O}_{3}$, arsenic trioxide; APL, acute promyelocytic leukemia; $\mathrm{As}_{2} \mathrm{~S}_{2}$, arsenic disulfide; $\mathrm{As}_{4} \mathrm{~S}_{4}$, tetra-arsenic tetra-sulfide; ATRA, all-trans-retinoic acid; MAPK, mitogenactivated protein kinase; PP1, protein phosphatase type 1; PP2A, protein phosphatase type $2 \mathrm{~A}$; MTP, mitochondrial transmembrane potential; MCL-1, myeloid cell leukemia-1; caspase, cysteinerequiring aspartate protease; GSTP1-1, glutathione S-transferase P1-1; MCL, mantle cell lymphoma; BCL-2, B-cell lymphoma-2; Bax, Bcl-2-associated X protein; SDS-PAGE, sodium dodecyl sulfate polyacrylamide gel electrophoresis; PMSF, phenylmethylsulfonyl fluoride

Key words: diffuse large B cell lymphoma, arsenic disulfide, apoptosis, Bax cleavage increasing $\mathrm{As}_{2} \mathrm{~S}_{2}$ concentration, and the results were also statistically significant. The quantitative PCR results showed that at the mRNA level, the $\mathrm{Bax} / \mathrm{Bcl}-2$ expression ratio was increased and caspase- 3 mRNA expression was upregulated in $\mathrm{As}_{2} \mathrm{~S}_{2}$-treated DLBCL cells. Western blot analysis revealed that at the protein level, $\mathrm{As}_{2} \mathrm{~S}_{2}$ increased the $\mathrm{Bax} / \mathrm{Bcl}-2$ protein ratio in contrast to decreased pro-caspase- 3 expression in the DLBCL cells. Our findings also demonstrated that 21-kDa Bax was proteolytically cleaved into the $18-\mathrm{kDa}$ Bax in the DLBCL cells exposed to $\mathrm{As}_{2} \mathrm{~S}_{2}$ at a concentration of $10 \mu \mathrm{M}$. $\mathrm{As}_{2} \mathrm{~S}_{2}$ inhibited proliferation and induced apoptosis of LY1 and LY8 cells in a concentration- and time-dependent manner. The effect was partly due to the induction of mitochondrialdependent apoptosis involving Bax cleavage.

\section{Introduction}

Non-Hodgkin lymphoma (NHL) is the most common hematological neoplasm in the United States, and accounts for $4 \%$ of all malignant tumors diagnosed each year (1). Diffuse large B cell lymphoma (DLBCL) is the most prevalent subtype of NHL worldwide and represents up to $40 \%$ of all NHL cases among adults in the Western world (2), and frequent in developing countries $(3,4)$. DLBCL is a heterogeneous disease with variable cytogenetics and immunophenotypes, as well as clinical features (5). Although the initial standard therapy with rituximab, cyclophosphamide, doxorubicin, vincristine, prednisone (R-CHOP) chemotherapy has improved outcomes for patients with DLBCL $(6,7), \sim 40 \%$ of patients are either refractory to initial treatment or relapse after standard therapy (8). For refractory and relapsed DLBCL patients who do not respond to high-dose therapy (HDT) and autologous stem cell transplantation (ASCT), the outcome is poor. Therefore, the discovery of novel and alternative therapeutic approaches is urgent.

Since arsenic trioxide $\left(\mathrm{As}_{2} \mathrm{O}_{3}\right)$ induces apoptosis in acute promyelocytic leukemia (APL) at a high concentration and mediates partial differentiation at a low concentration (9), arsenic drugs have become a 'hot topic' and have attracted increased attention in regards to malignant hematological neoplasms and other solid tumors (10-13). Arsenic drugs, including arsenic disulfide $\left(\mathrm{As}_{2} \mathrm{~S}_{2}\right)$, tetra-arsenic tetra-sulfide 
$\left(\mathrm{As}_{4} \mathrm{~S}_{4}\right)$ and arsenic trioxide $\left(\mathrm{As}_{2} \mathrm{O}_{3}\right)$, have similar antitumor effects. $\mathrm{As}_{2} \mathrm{~S}_{2}$, one of the main ingredients of realgar, has been chosen as an anticancer candidate due to its superior effectiveness, advantage of oral administration and low toxicity in Chinese traditional medicine.

Realgar has been found to induce both apoptosis and differentiation simultaneously in all-trans-retinoic acid (ATRA)-sensitive NB4 and ATRA-resistant MR2PML-RARa ${ }^{+}$ APL cell lines (14). Previous studies have demonstrated that realgar induced apoptosis of HL-60, NB4 and K562 cell lines, which was associated with CD95/CD95L and MAPK pathway, inhibition of telomerase activity and decreased expression of BCL-2 and PNAS-2 (15-18). In addition, realgar induced the differentiation of the HL-60 cell line via not only the enhancement of the activity of serine/threonine protein phosphatase type 1 (PP1) and type 2A (PP2A) but also oxidative stress and stress-related mitochondrial transmembrane potential (MTP) $(16,19)$.

In addition, previous studies have demonstrated that arsenic induced apoptosis in NHL cells by means of different mechanisms. They revealed that $\mathrm{As}_{2} \mathrm{O}_{3}$ inhibited proliferation and induced apoptosis in the human Burkitt lymphoma cell line Raji and in the human T lymphoma cell line Jurkat through cell cycle arrest, decrease in respiratory function and MTP, downregulating the expression of MCL-1 and subsequently activating caspase-3 (20-23). However Jurkat cells were less sensitive to $\mathrm{As}_{2} \mathrm{O}_{3}$-induced apoptosis than Raji cells, as Jurkat cells express high levels of glutathione S-transferase P1-1 (GSTP1-1) $(21,23)$. At the same time, realgar induced apoptosis of the human $\mathrm{T}$ lymphocyte leukemia cell line CEM through cell cycle arrest in the G2/M phase, a decrease in the expression of Bcl-2 and an increase in Apo2.7 protein expression (24). A recent study demonstrated that $\mathrm{As}_{2} \mathrm{O}_{3}$ inhibited the growth of mantle cell lymphoma (MCL) and induced apoptosis through a decrease in cyclin D1 expression and increase in the expression of apoptosis-related molecules (25).

However, whether $\mathrm{As}_{2} \mathrm{~S}_{2}$ induces the apoptosis of DLBCL cells remains unknown. Since induction of apoptosis has been used as an important target with which to evaluate new antitumor drugs, it is necessary to study the antitumor mechanisms of $\mathrm{As}_{2} \mathrm{~S}_{2}$. For the first time, our present study focused on the effects of $\mathrm{As}_{2} \mathrm{~S}_{2}$ on the proliferation and apoptosis of DLBCL cell lines and the related mechanisms. We demonstrated that $\mathrm{As}_{2} \mathrm{~S}_{2}$ inhibited the proliferation and induced the apoptosis of DLBCL cells in a concentration- and time-dependent manner. We also demonstrated that the effect was partly due to the induction of mitochondrial-dependent apoptosis involving Bax cleavage.

\section{Materials and methods}

Cell lines and cell culture. The human DLBCL cell lines LY1 and LY8 were maintained as suspension cells at $37^{\circ} \mathrm{C}$ in $5 \%$ carbon dioxide in a humidified atmosphere. LY1 and LY8 cells were cultured in Iscove's modified Dulbecco's medium (IMDM) supplemented with 10\% fetal bovine serum (FBS) (both from HyClone, Logan, UT, USA). LY1 and LY8 cells in the exponential growth phase were seeded into 96 -well plates or culture flasks.
Antibodies and reagents. $\mathrm{As}_{2} \mathrm{~S}_{2}$ (99.53\% in purity) was purchased from Alfa Aesar Company (Shanghai, China). For studies, $\mathrm{As}_{2} \mathrm{~S}_{2}$ was dissolved in $0.1 \mathrm{M}$ sodium hydroxide $(\mathrm{NaOH})$, and hydrochloric acid $(\mathrm{HCl})$ was used to adjust the $\mathrm{pH}$ to $7.35-7.45$. The stock solution $\left(1 \mathrm{mM} \mathrm{As}_{2} \mathrm{~S}_{2}\right)$ was then passed through a $0.22-\mu \mathrm{m}$ filter. To prepare working solutions, aliquots were further diluted in IMDM supplemented with 10\% FBS immediately before each experiment. Rabbit anti-Bcl-2, -Bax and -caspase-3 monoclonal antibodies were purchased from Cell Signaling Technology, Inc. (Boston, MA, USA). Mouse anti- $\beta$-actin polyclonal antibody was purchased from Zhongshan Golden Bridge (Beijing, China).

Assessment of the cytotoxic effect of $\mathrm{As}_{2} \mathrm{~S}_{2}$ by Cell Counting Kit-8 (CCK-8). Cell proliferation was measured by the CCK-8 assay (Beyotime, China). LY1 and LY8 cell lines $\left(1 \times 10^{4}\right.$ cells $/ 100 \mu 1 /$ well, respectively) were seeded into 96-well plates, treated with various concentrations of $\mathrm{As}_{2} \mathrm{~S}_{2}$ and cultured for 24, 48 and $72 \mathrm{~h}$ in a humidified atmosphere in a $5 \%$ carbon dioxide incubator. All experiments were performed in triplicate and repeated 3 times. Cells were incubated with $10 \mu \mathrm{l}$ of CCK- 8 at $37^{\circ} \mathrm{C}$ for $4 \mathrm{~h}$. Then the optical density (OD) for each well was measured at $450 \mathrm{~nm}$ using an ELISA reader. The inhibitory concentration of $50 \%$ of cells $\left(\mathrm{IC}_{50}\right)$ was obtained using probit regression analysis method. The cell viability rate was calculated according to the following equation: Cell viability rate $=(\mathrm{OD}$ experiment - OD blank $) /$ (OD control - OD blank) x 100\%.

Assessment of apoptosis by Annexin $V$ and propidium iodide. Induction of apoptosis was assessed using the Annexin V-fluorescein isothiocyanate (FITC) apoptosis detection kit (KeyGen Biotech, China). LY1 and LY8 cells were treated with $\mathrm{As}_{2} \mathrm{~S}_{2}$ at 2, 4, 6, 8 and $10 \mu \mathrm{M}$. Cell culture medium without $\mathrm{As}_{2} \mathrm{~S}_{2}$ was added to the untreated control. Dual staining with Annexin V-FITC and propidium iodide (PI) was carried out according to the manufacturer's instructions. The cells $\left(5-10 \times 10^{5}\right)$ were analyzed by flow cytometry (Becton-Dickinson, USA). The acquired data were processed with FlowJo7.6 software. Annexin V-FITC and PI-negative cells were identified as viable cells. Cells exhibiting Annexin V-FITC-positive and PI-negative staining were considered to be early apoptotic cells while those with both Annexin V-FITC and PI-positive staining were considered late apoptotic cells. The sum of early and late apoptotic cells constituted the apoptotic cell population.

Gene expression study by quantitative real-time PCR. Total RNA was extracted from the $\mathrm{As}_{2} \mathrm{~S}_{2}$-treated and untreated DLBCL cell lines using TRIzol (Invitrogen Life Technologies, Carlsbad, CA, USA). Then reverse transcription reaction was conducted by means of Takara reverse transcription reagents (Takara, Dalian, China). Amplification reactions were performed using SYBR Premix Ex Taq (Takara) using the Roche LightCycler 480 Real-Time quantitative PCR system. Specific primers for RT-PCR were obtained from Sangon Biotech (Shanghai, China), and the primer sequences are listed in Table I. Expression data were normalized to the geometric mean of housekeeping gene $\beta$-actin to control the variability in expression levels. For data analysis, the $2^{-\Delta \Delta C t}$ method was 
Table I. Primers used for the quantitative real-time PCR.

\begin{tabular}{ll}
\hline Gene & \multicolumn{1}{c}{ Primer sequence } \\
\hline$\beta$-actin & Forward: 5'-TGACGTGGACATCCGCAAAG-3' \\
& Reverse: 5'-CTGGAAGGTGGACAGCGAGG-3' \\
Bax & Forward: 5'-CCCGAGAGGTCTTTTTCCGAG-3' \\
& Reverse: 5'-CCAGCCCATGATGGTTCTGAT-3' \\
Bcl-2 & Forward: 5'-ATGTGTGTGGAGAGCGTCAA-3' \\
& Reverse: 5'-ACAGTTCCACAAAGGCATCC-3' \\
Caspase-3 & Forward: 5'-GACTCTGGAATATCCCTGGgACAACA-3' \\
& Reverse: 5'-AGGTTTGCTGCATCGACATCTG-3' \\
\hline
\end{tabular}
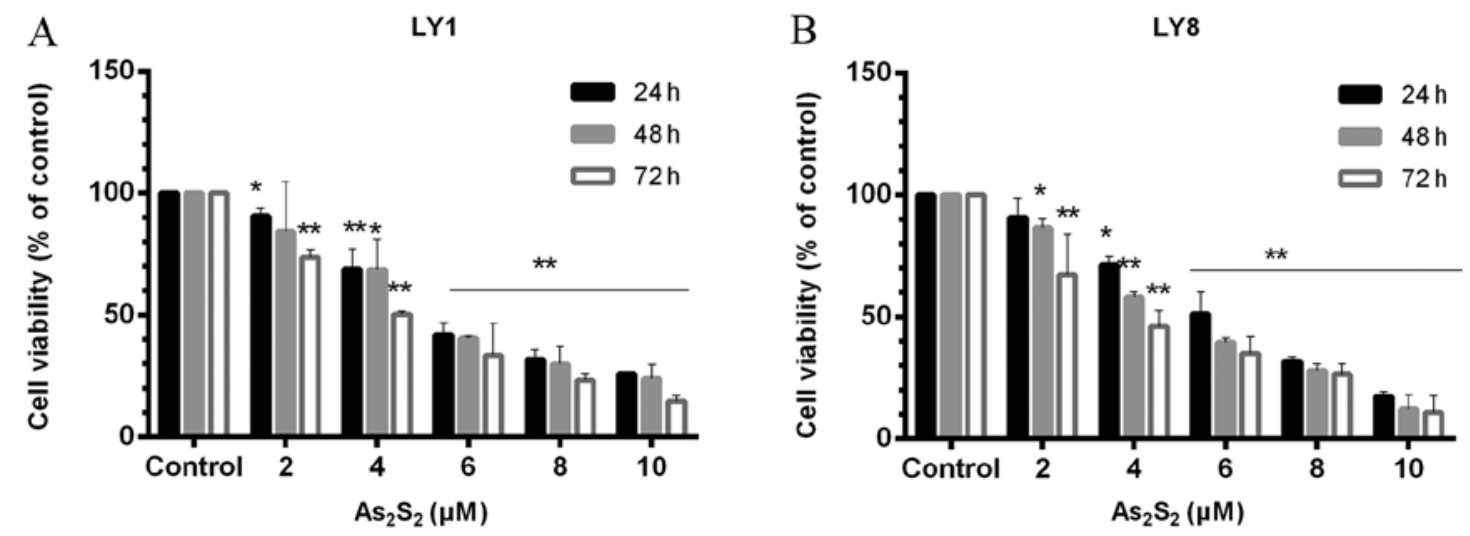

Figure 1. Effects of $\mathrm{As}_{2} \mathrm{~S}_{2}$ on the viability of DLBCL cells. (A) LY1 and (B) LY8 cells were incubated with various concentrations of $\mathrm{As}_{2} \mathrm{~S}_{2}(2,4,6,8$ and $10 \mu \mathrm{M})$ for 24,48 and $72 \mathrm{~h}$. CCK- 8 assay was used to evaluate the cell viability. The data are presented as the percentages of the corresponding untreated control. The data are from untreated cells (control) and from $\mathrm{As}_{2} \mathrm{~S}_{2}$-treated cells at different concentrations $(2-10 \mu \mathrm{M})$. Values are expressed as means $\pm \mathrm{SD}$. "P<0.05, statistically significant difference compared with the untreated control, and ${ }^{* * *} \mathrm{P}<0.01$, compared with the untreated control. As $\mathrm{S}_{2}$, arsenic disulfide; DLBCL, diffuse large B cell lymphoma; CCK-8, Cell Counting kit-8.

used. Real-time PCR for each gene of each cDNA sample was assayed in triplicate.

$\Delta \mathrm{Ct}=\mathrm{Ct}$ (target gene) $-\mathrm{Ct}(\beta$-actin gene)

$\Delta \Delta \mathrm{Ct}=\Delta \mathrm{Ct}\left(\mathrm{As}_{2} \mathrm{~S}_{2}\right.$-treated cells) $-\Delta \mathrm{Ct}$ (untreated control)

Protein expression study by western blot analysis. Sodium dodecyl sulfate polyacrylamide gel electrophoresis (SDS-PAGE) and western blotting were performed to evaluate the protein levels of Bax, Bcl-2 and caspase-3. Total protein was extracted from $\mathrm{As}_{2} \mathrm{~S}_{2}$-treated and untreated DLBCL cells using RIPA and 1\% PMSF (Shenergy Biocolor, Shanghai, China). The protein concentration of the samples was determined by the BCA assay (Shenergy Biocolor). Proteins were detected using the chemiluminescence detection kit (Millipore, Billerica, MA, USA). Western blotting results were analyzed using Las-4000 Image software and Multi Gauge Ver. 3.0 software (Fujifilm Life Science, Japan).

Statistical analysis. Statistical analysis was performed using SPSS 17.0. The data are reported as means \pm standard deviation (SD). ANOVA was used to evaluate data from the cell viability assays and for the cell apoptotic rates. Other statistical analyses of data were performed using the Student's t-test. Statistical significance was defined as $\mathrm{P}<0.05$.

\section{Results}

$\mathrm{As}_{2} \mathrm{~S}_{2}$ inhibits the proliferation of DLBCL cells. The effect of $\mathrm{As}_{2} \mathrm{~S}_{2}$ on the cell viability of DLBCL cells was evaluated by CCK-8 assay. A significant decrease in cell viability was observed after the LY1 and LY8 cells were incubated with different doses of $\mathrm{As}_{2} \mathrm{~S}_{2}(2,4,6,8$ and $10 \mu \mathrm{M})$ for different time periods (24, 48 and $72 \mathrm{~h}$ ) (Fig. 1). Compared with the untreated control, treatment with $2 \mu \mathrm{M} \mathrm{As}_{2} \mathrm{~S}_{2}$ for $24 \mathrm{~h}$ resulted in a viability of $90.75 \pm 3.13$ and $84.18 \pm 2.45 \%$ in LY1 and LY8 cells, respectively $(\mathrm{P}<0.05)$. The inhibitory effect on cell viability was enhanced along with increasing $\mathrm{As}_{2} \mathrm{~S}_{2}$ doses and incubation times. The cell viability rate was $14.62 \pm 2.15$ and $10.84 \pm 6.67 \%$ in the LY1 and LY8 cells, respectively when the treatment time increased to $72 \mathrm{~h}$. The $\mathrm{IC}_{50}$ of LY1 and LY8 cells at $48 \mathrm{~h}$ was 9.884 and $10.540 \mu \mathrm{M}$, respectively.

$A s_{2} S_{2}$ induces the apoptosis of DLBCL cells. To determine the effect of $\mathrm{As}_{2} \mathrm{~S}_{2}$-induced apoptosis in LY1 and LY8 cells, Annexin V-FITC/PI dual staining followed by flow cytometric analysis was assessed. As shown in Figs. 2 and $3, \mathrm{As}_{2} \mathrm{~S}_{2}$ induced apoptosis in LY1 and LY8 cells in a concentration- and time-dependent manner. Exposure to $\mathrm{As}_{2} \mathrm{~S}_{2}$ at concentrations of 2-10 $\mu \mathrm{M}$ for $24 \mathrm{~h}$ led to a relatively low rate of apoptosis. 
A

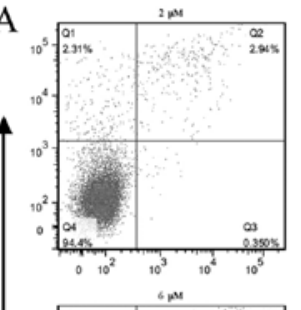

$24 \mathrm{~h}$
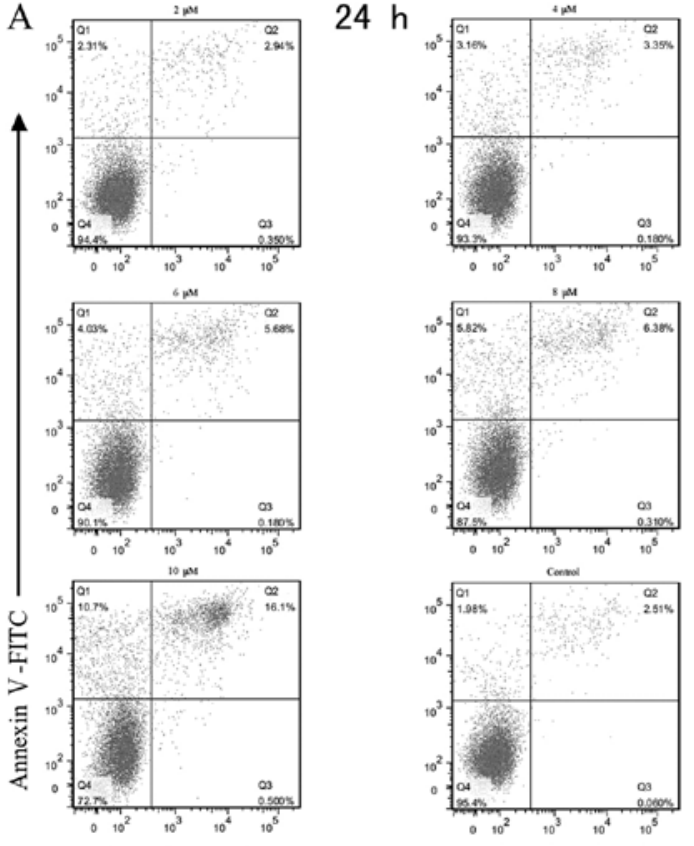

$\mathrm{C}$
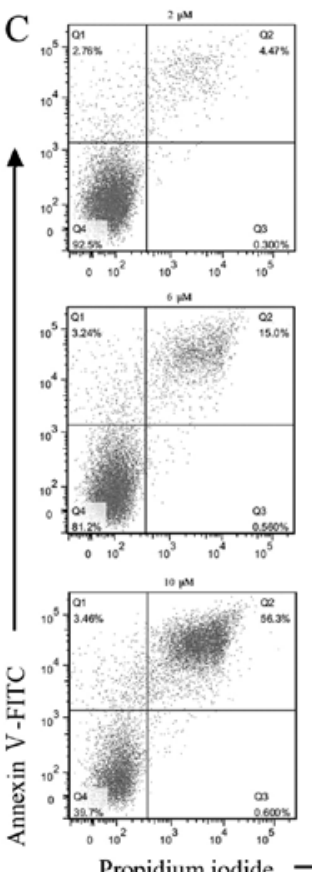

$72 \mathrm{~h}$
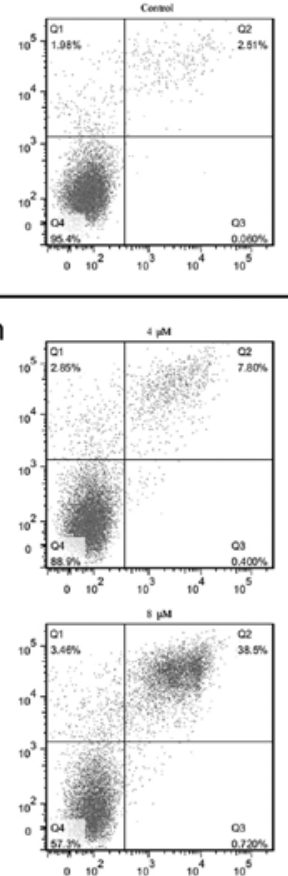

B
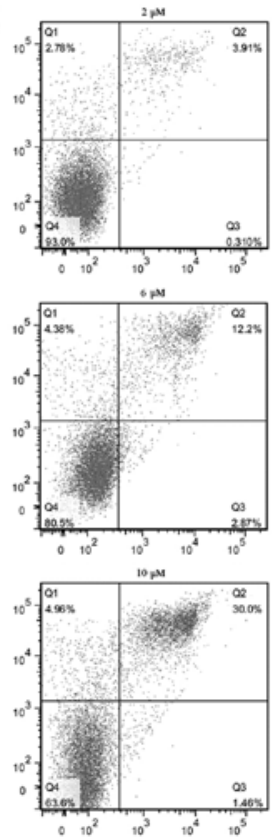

$48 \mathrm{~h}$
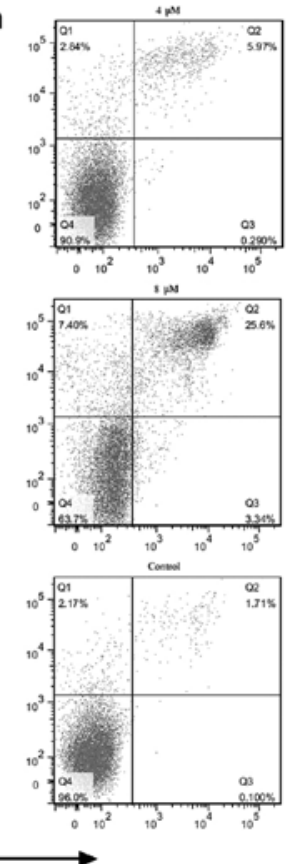

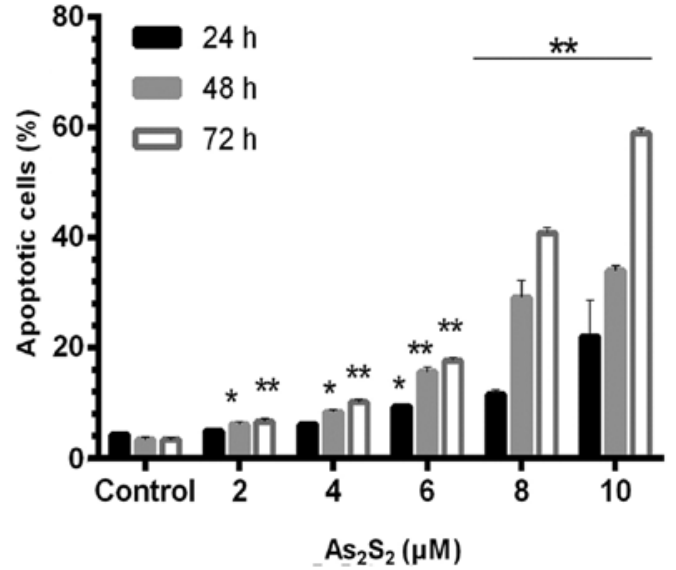

Figure 2. Effects of $\mathrm{As}_{2} \mathrm{~S}_{2}$ on the apoptosis of LY1 cells. LY1 cells were incubated with $\mathrm{As}_{2} \mathrm{~S}_{2}$ at various concentrations of 2, 4, 6, 8 and $10 \mu \mathrm{M}$ for (A) 24, (B) 48 and (C) $72 \mathrm{~h}$. The apoptosis rate was determined by Annexin V-FITC/PI dual staining followed by flow cytometric analysis. The lower left upper quadrant (Q4) shows the percentage of viable cells (Annexin V-FITC and PI-negative), the left quadrant (Q1) shows the percentage of early apoptotic cells (Annexin V-FITCpositive and PI-negative), and the upper right quadrant (Q2) indicates the percentage of late apoptotic cells (Annexin V-FITC and PI-positive). The apoptosis of cells was induced by $\mathrm{As}_{2} \mathrm{~S}_{2}$ in a concentration- and time-dependent manner. Values are expressed as means $\pm \mathrm{SD}$. ${ }^{*} \mathrm{P}<0.05$, statistically significant difference compared with the untreated control, and ${ }^{* *} \mathrm{P}<0.01$, compared with the untreated control. $\mathrm{As}_{2} \mathrm{~S}_{2}$, arsenic disulfide.

In contrast, exposure to $\mathrm{As}_{2} \mathrm{~S}_{2}$ at the same concentrations for $72 \mathrm{~h}$ resulted in a more notable apoptosis. After treatment with various doses of $\mathrm{As}_{2} \mathrm{~S}_{2}$, the maximal apoptosis rate was $22.06 \pm 6.54 \%$ in LY1 cells and $27.30 \pm 6.56 \%$ in LY8 cells, respectively, at $24 \mathrm{~h}$. When the treatment time increased to $72 \mathrm{~h}$, the maximal apoptosis rate was $58.94 \pm 0.79 \%$ in LY1 cells and $61.30 \pm 6.06 \%$ in LY8 cells. In contrast, not more than $5 \%$ of the untreated control DLBCL cells underwent apoptosis under the same conditions.
$\mathrm{As}_{2} \mathrm{~S}_{2}$ increases the Bax/Bcl-2 ratio and upregulates caspase- 3 expression at the $m R N A$ level. To further investigate whether the $\mathrm{As}_{2} \mathrm{~S}_{2}$-induced apoptosis is dependent on the mitochondrial-mediated apoptosis pathway, the effect of $\mathrm{As}_{2} \mathrm{~S}_{2}$ on the mRNA levels of Bax, Bcl-2 and caspase-3 genes was measured by quantitative real-time PCR. Following treatment with $10 \mu \mathrm{M} \mathrm{As}_{2} \mathrm{~S}_{2}$ for $48 \mathrm{~h}$, the expression of Bax mRNA in LY1 cells was upregulated by $\sim 2$-fold while Bcl-2 mRNA expression was reduced by more than half (Fig. 4). Yet, no significant 
A
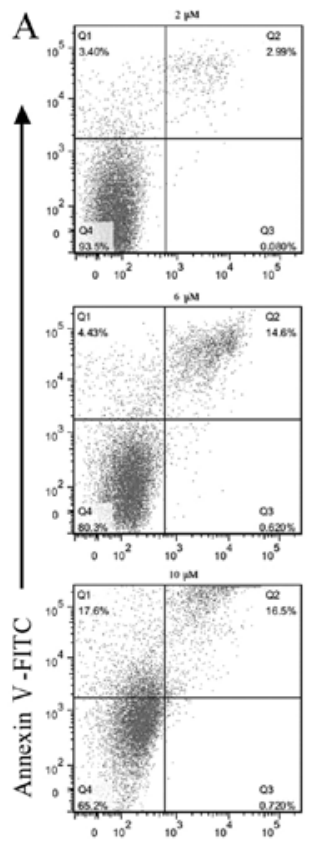

Propidium iodide
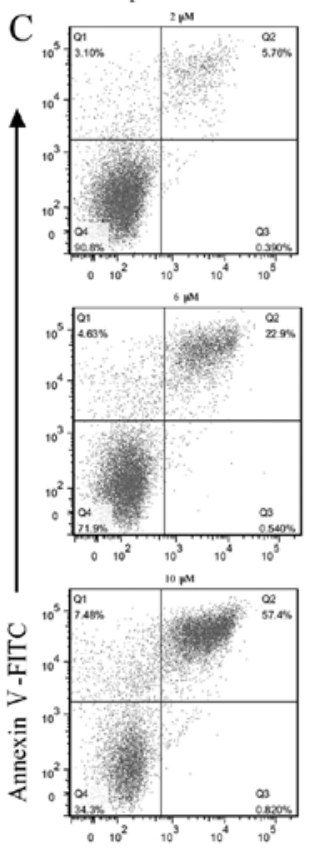

Propidium iodide
$24 \mathrm{~h}$
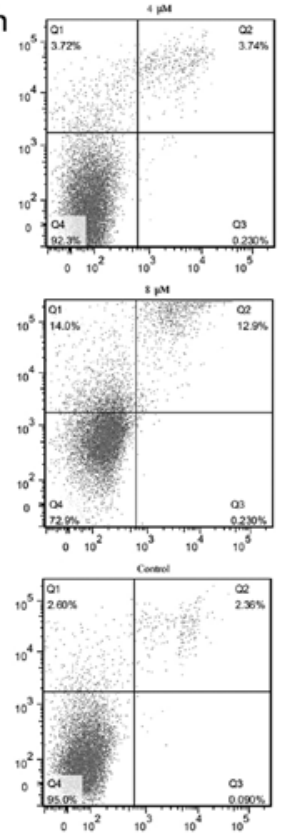

$72 \mathrm{~h}$
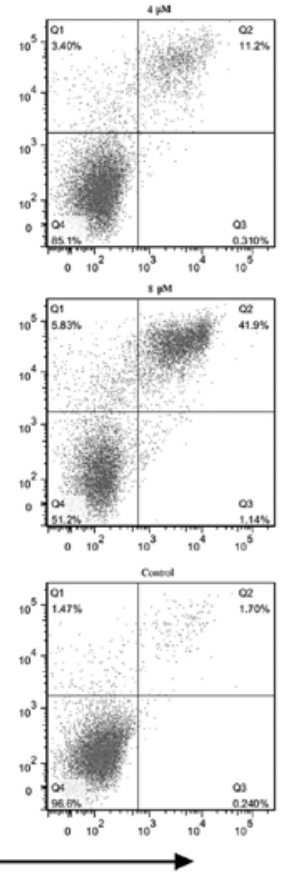

B
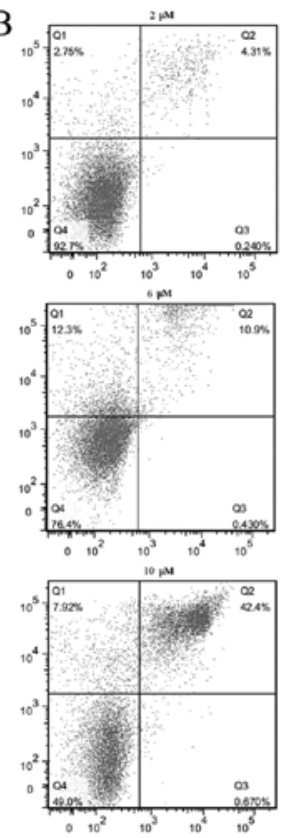

$48 \mathrm{~h}$
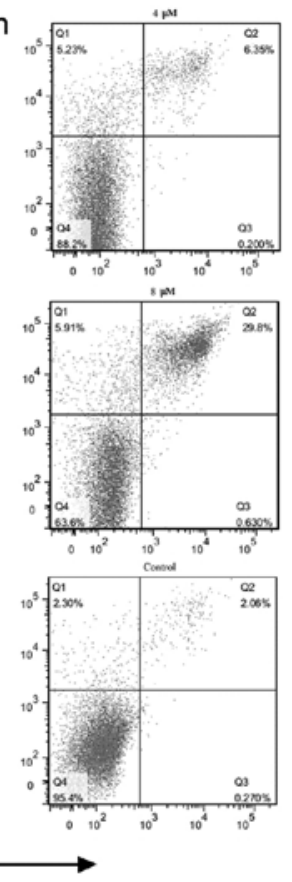

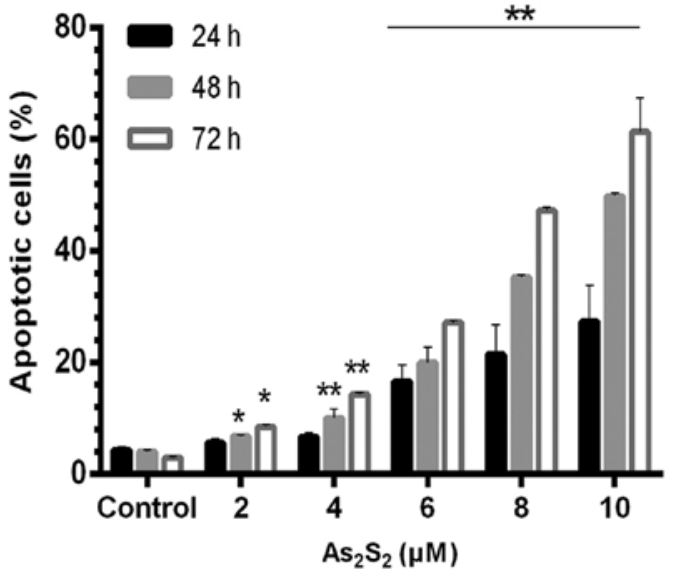

Figure 3. Effects of $\mathrm{As}_{2} \mathrm{~S}_{2}$ on apoptosis of LY8 cells. LY8 cells were incubated with $\mathrm{As}_{2} \mathrm{~S}_{2}$ at various concentrations of 2, 4, 6, 8 and 10 $\mu \mathrm{M}$ for (A) 24, (B) 48 and (C) $72 \mathrm{~h}$. The apoptosis rate was determined by the Annexin V-FITC/PI dual staining followed by flow cytometric analysis. The lower left upper quadrant (Q4) shows the percentage of viable cells (Annexin V-FITC and PI negative), the left quadrant (Q1) shows the percentage of early apoptotic cells (Annexin V-FITCpositive and PI-negative), and the upper right quadrant (Q2) indicates the percentage of late apoptotic cells (Annexin V-FITC and PI-positive). The apoptosis of cells was induced by $\mathrm{As}_{2} \mathrm{~S}_{2}$ in a concentration- and time-dependent manner. Values are expressed as means $\pm \mathrm{SD}$. ${ }^{*} \mathrm{P}<0.05$, statistically significant difference compared with the untreated control, and ${ }^{* *} \mathrm{P}<0.01$, compared with the untreated control. $\mathrm{As}_{2} \mathrm{~S}_{2}$, arsenic disulfide.

difference in expression of Bcl-2 was observed between the $\mathrm{As}_{2} \mathrm{~S}_{2}$-treated LY8 cells and the untreated controls. In addition, the Bax/Bcl-2 ratio was significantly upregulated by $\sim 3$-fold in the LY1 and LY8 cells. The expression of caspase-3 was markedly upregulated in the LY1 and LY8 cells.

$\mathrm{As}_{2} \mathrm{~S}_{2}$ increases the Bax/Bcl-2 ratio in comparison to a decrease in pro-caspase-3 expression in DLBCL cells at the protein level. We also investigated whether the protein expression levels of Bax, Bcl-2 and caspase-3 were altered after the $\mathrm{As}_{2} \mathrm{~S}_{2}$ treatment. As shown in Fig. 5, after treatment with different doses of $\mathrm{As}_{2} \mathrm{~S}_{2}(2$ and $10 \mu \mathrm{M})$ for $48 \mathrm{~h}$, the Bcl-2 expression was markedly downregulated whereas Bax expression was substantially upregulated in the LY1 and LY8 cells. In addition, the $\mathrm{Bax} / \mathrm{Bcl}-2$ ratio was significantly upregulated. Western blotting also demonstrated that after exposure to $2 \mu \mathrm{M}$ 

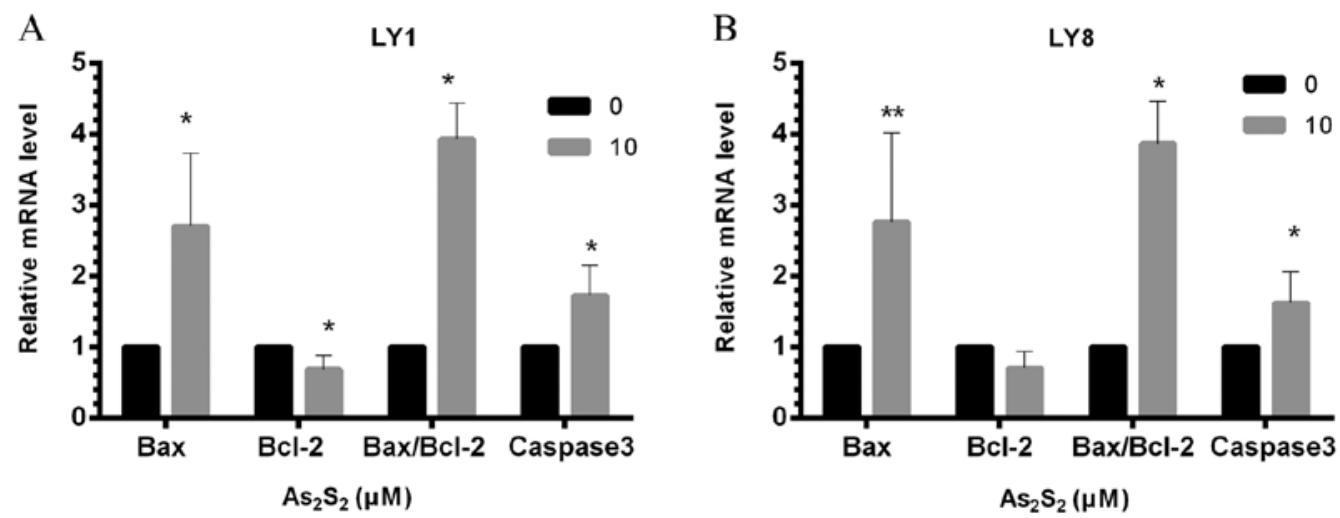

Figure 4. Effects of $\mathrm{As}_{2} \mathrm{~S}_{2}$ on the transcriptional levels of Bax, Bcl-2 and caspase-3 genes in the DLBCL cells. The relative mRNA levels of Bax, Bcl-2 and caspase-3 genes were assessed by quantitative real-time PCR after treatment with $10 \mu \mathrm{M} \mathrm{As}_{2} \mathrm{~S}_{2}$ for $48 \mathrm{~h}$ in (A) LY1 and in (B) LY8 cells. Values are expressed as means $\pm \mathrm{SD}$; ${ }^{*} \mathrm{P}<0.05,{ }^{* * *} \mathrm{P}<0.01$ compared with the untreated control. $\mathrm{As}_{2} \mathrm{~S}_{2}$, arsenic disulfide; DLBCL, diffuse large B cell lymphoma.

A

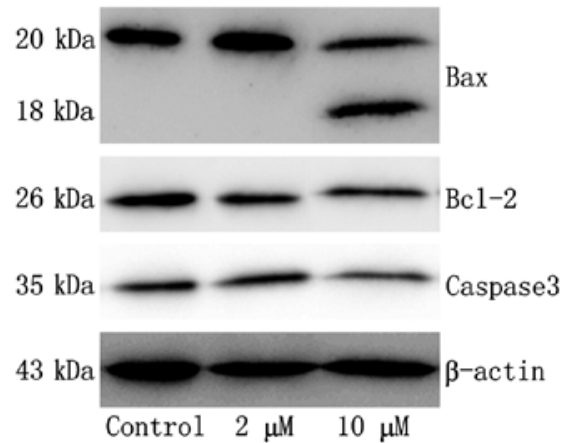

$\mathrm{C}$

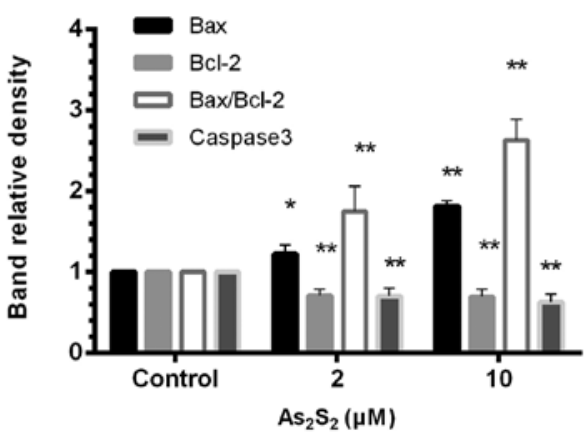

B LY8

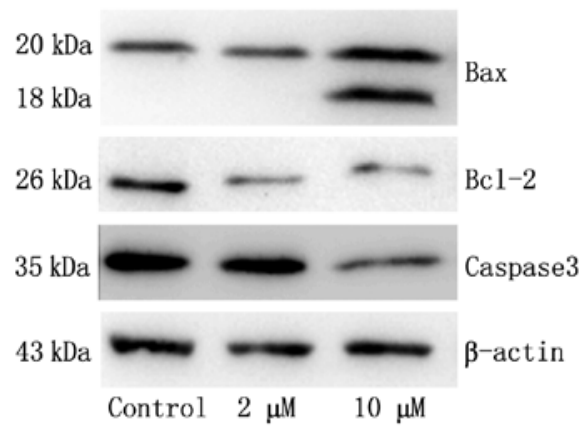

LY8

$\mathrm{D}$

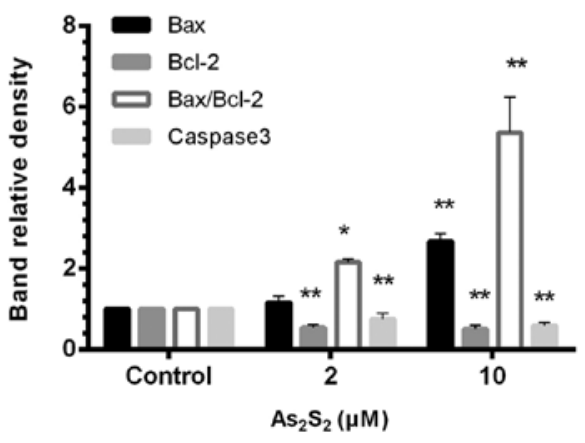

Figure 5. Effects of $\mathrm{As}_{2} \mathrm{~S}_{2}$ on the levels of Bax, Bcl-2 and caspase-3 protein in the DLBCL cells. (A) LY1 and (B) LY8 cells were treated with 2 and $10 \mu \mathrm{M}$ As $\mathrm{S}_{2}$ for $48 \mathrm{~h}$. Western blotting was used to analyze whole cell lysates for Bax, Bcl-2 and caspase-3 expression following $\mathrm{As}_{2} \mathrm{~S}_{2}$ treatment. Actin expression was used as an internal control. ( $\mathrm{C}$ and $\mathrm{D}$ ) The relative density of caspase-3 and the $\mathrm{Bax} / \mathrm{Bcl}-2$ ratio were calculated from 3 separate experiments. $\mathrm{P}<0.05$, indicates a statistically significant difference compared with the untreated control, and ${ }^{* *} \mathrm{P}<0.01$, compared with the untreated control. $\mathrm{As}_{2} \mathrm{~S}_{2}$, arsenic disulfide; DLBCL, diffuse large B cell lymphoma.

$\mathrm{As}_{2} \mathrm{~S}_{2}$, the levels of 21-kDa Bax were increased but Bax was not detectably cleaved. In contrast, after exposure to $10 \mu \mathrm{M}$ $\mathrm{As}_{2} \mathrm{~S}_{2}$, not only the levels of the $21-\mathrm{kDa}$ Bax protein were increased but also Bax cleavage (18-kDa Bax) was substantial. Concomitantly, pro-caspase-3 expression was evidently downregulated.

\section{Discussion}

In the present study, we demonstrated that $\mathrm{As}_{2} \mathrm{~S}_{2}$ significantly inhibited proliferation and induced apoptosis in the LY1 and
LY8 cells. In addition, we also found that the mechanism by which $\mathrm{As}_{2} \mathrm{~S}_{2}$ induced apoptosis was through the mitochondrialmediated pathway which involved concomitant Bax cleavage. Therefore, this is the first study concerning the effects of $\mathrm{As}_{2} \mathrm{~S}_{2}$ on DLBCL cells in vitro.

It is widely believed that apoptosis is initiated by two major pathways: the extrinsic pathway and the intrinsic pathway (26). The intrinsic pathway is characterized by mitochondrial dysfunction with release of caspase activators, followed by activation of caspase- 9 and -3 . Mitochondrial-induced apoptosis requires involvement of the Bcl-2 family (27), which 
consists of anti-apoptotic proteins, multi-domain pro-apoptotic proteins and $\mathrm{BH} 3$-only pro-apoptotic proteins $(28,29)$. It is known that Bax and Bcl-2 are representative members of the Bcl-2 family; Bax promotes apoptosis and Bcl-2 inhibits apoptosis. The apoptosis inducing-effect is more dependent on the ratio of $\mathrm{Bax} / \mathrm{Bcl}-2$ than on individual $\mathrm{Bax}$ and $\mathrm{Bcl}-2$ quantity (30). Accordingly, the ratio of $\mathrm{Bax} / \mathrm{Bcl}-2$ is frequently used as an index of apoptosis (31). As expected, we observed that the ratio of $\mathrm{Bax} / \mathrm{Bcl}-2$ in the $\mathrm{As}_{2} \mathrm{~S}_{2}$-treated cells was significantly increased when compared with the control cells, not only at the mRNA but also at the protein level which was consistent with a previous study (24).

Notably, western blot analysis of Bax protein expression showed that a smaller band of $\sim 18 \mathrm{kDa}$ was produced in addition to a $21-\mathrm{kDa}$ band when DLBCL cells were exposed to $\mathrm{As}_{2} \mathrm{~S}_{2}$ at a concentration of $10 \mu \mathrm{M}$. In contrast, $18-\mathrm{kDa} \mathrm{Bax}$ was not detected in the control cells and the $\mathrm{As}_{2} \mathrm{~S}_{2}$-treated cells at a concentration of $2 \mu \mathrm{M}$. Staining with $\beta$-actin antibody confirmed that the observed discrimination in protein expression was not caused by a different protein quantity/lane. It is well known that $21-\mathrm{kDa}$ Bax exists primarily in the cytosol and rapidly translocates to mitochondria upon the induction of apoptosis where $21-\mathrm{kDa}$ Bax is cleaved into a $18-\mathrm{kDa}$ fragment (18-kDa Bax). The reason for Bax cleavage may be explained by the fact that Bax underwent conformational change in the presence of cytotoxic $\mathrm{As}_{2} \mathrm{~S}_{2}$. It has been reported that Bax cleavage occurs in lymphoma cell lines, myeloid leukemia cells, chronic lymphocyte leukemia and other solid tumor cell lines treated with various chemotherapeutic agents (32-51). Previous studies have demonstrated that $18-\mathrm{kDa} \mathrm{Bax}$, a characteristic feature of Bax activation, behaves similar to the $\mathrm{BH} 3$-only protein and is a more potent inducer of apoptosis than 21-kDa Bax. Further research confirmed that interruption of Bax cleavage obviously reduces drug-induced apoptosis, while depression of 18-kDa Bax degradation significantly augments drug-mediated apoptosis $(34,47,52)$. In addition, Bax cleavage is thought to be triggered by calpain-dependent protease, which has been reported to occur at different sites $(38,47,53-55)$. Previous research also found that $\mathrm{As}_{2} \mathrm{O}_{3}$-induced cleavage of Bax was partially blocked by calpeptin in neuroblastoma cells, which demonstrates that calpain is involved in the process of Bax cleavage $(56,57)$. Thus, we hypothesized that $\mathrm{As}_{2} \mathrm{~S}_{2}$-induced cleavage of Bax in DLBCL cells may be calpain-dependent, which requires further investigation. Therefore, our findings suggest that Bax is critical for the initiation of apoptosis of $\mathrm{As}_{2} \mathrm{~S}_{2}$-treated DLBCL cells. This is the first study to demonstrate the role of Bax in $\mathrm{As}_{2} \mathrm{~S}_{2}$-induced apoptosis.

We further investigated the potential involvement of caspases in the induction of apoptosis by $\mathrm{As}_{2} \mathrm{~S}_{2}$ in the LY1 and LY8 cells. Caspase activation plays a key role in the course of mitochondrial-mediated apoptosis (58). Firstly, release of cytochrome $c$ in the cytoplasm activates caspase-9, which then activates caspase- 3 in a cascade. The common terminal mediator of mitochondrial death cascade is activation of caspase-3 which is responsible for initiating the apoptotic program. In the present study, the upregulation of the ratio of Bax/Bcl-2 protein occurred in LY1 and LY8 cells after treatment with $\mathrm{As}_{2} \mathrm{~S}_{2}$, which resulted in the activation of caspase-3. Moreover, our findings demonstrated the downregulation of pro-caspase-3, which may indirectly indicate its cleavage and the increase in the level of the active form of caspase-3.

In conclusion, the search for novel and effective treatments for DLBCL remains a challenge. Our findings found that $\mathrm{As}_{2} \mathrm{~S}_{2}$ inhibited the proliferation and induced the apoptosis of DLBCL cells in vitro through the mitochondrial pathway. In addition, Bax was critical for the initiation of apoptosis in $\mathrm{As}_{2} \mathrm{~S}_{2}$-treated DLBCL cells. Thus, $\mathrm{As}_{2} \mathrm{~S}_{2}$ may be useful as a potential therapeutic agent against DLBCL and further research is warranted.

\section{Acknowledgements}

The authors thank the Central Laboratory of Provincial Hospital Affiliated to Shandong University helps. This study was supported by the grants from the National Natural Science Foundation (no. 81270598), the Natural Science Foundation of Shandong Province, China (nos. ZR2009CM059 and ZR2012HZ003) and the Project of Scientific and Technological Development of Shandong Province, China (no. 2010GSF10250) to Professor X.W.

\section{References}

1. Cultrera JL and Dalia SM: Diffuse large B-cell lymphoma: current strategies and future directions. Cancer Control 19: 204-213, 2012.

2. Nedomova R, Papajik T, Prochazka V, Indrak K and Jarosova M: Cytogenetics and molecular cytogenetics in diffuse large B-cell lymphoma (DLBCL). Biomed Pap Med Fac Univ Palacky Olomouc Czech Repub: Nov 6, 2012 (Epub ahead of print). doi: $10.5507 / \mathrm{bp} .2012 .085$.

3. Abid MB, Nasim F, Anwar K and Pervez S: Diffuse large B cell lymphoma (DLBCL) in Pakistan: an emerging epidemic? Asian Pac J Cancer Prev 6: 531-534, 2005.

4. Sabattini E, Bacci F, Sagramoso C and Pileri SA: WHO classification of tumours of haematopoietic and lymphoid tissues in 2008: an overview. Pathologica 102: 83-87, 2010.

5. Tirado CA, Chen W, García R, Kohlman KA and Rao N: Genomic profiling using array comparative genomic hybridization define distinct subtypes of diffuse large B-cell lymphoma: a review of the literature. J Hematol Oncol 5: 54, 2012.

6. Cang S, Mukhi N, Wang K and Liu D: Novel CD20 monoclonal antibodies for lymphoma therapy. J Hematol Oncol 5: 64, 2012.

7. Stefancikova L, Moulis M, Fabian P, et al: Prognostic impact of p53 aberrations for R-CHOP-treated patients with diffuse large B-cell lymphoma. Int J Oncol 39: 1413-1420, 2011.

8. Jin X, Ding H, Ding N, Fu Z, Song Y and Zhu J: Homozygous A polymorphism of the complement C1qA276 correlates with prolonged overall survival in patients with diffuse large B cell lymphoma treated with R-CHOP. J Hematol Oncol 5: 51, 2012.

9. Jing Y, Dai J, Chalmers-Redman RM, Tatton WG and Waxman S: Arsenic trioxide selectively induces acute promyelocytic leukemia cell apoptosis via a hydrogen peroxide-dependent pathway. Blood 94: 2102-2111, 1999.

10. Iriyama N, Yoshino Y, Yuan B, et al: Speciation of arsenic trioxide metabolites in peripheral blood and bone marrow from an acute promyelocytic leukemia patient. J Hematol Oncol 5: 1, 2012.

11. Galimberti S, Guerrini F, Salvi F, et al: Arsenic trioxide and ascorbic acid interfere with the BCL2 family genes in patients with myelodysplastic syndromes: an ex-vivo study. J Hematol Oncol 5: 53, 2012.

12. Chen G, Wang K, Yang BY, Tang B, Chen JX and Hua ZC: Synergistic antitumor activity of oridonin and arsenic trioxide on hepatocellular carcinoma cells. Int J Oncol 40: 139-147, 2012.

13. Ong PS, Chan SY and Ho PC: Differential augmentative effects of buthionine sulfoximine and ascorbic acid in $\mathrm{As}_{2} \mathrm{O}_{3}$-induced ovarian cancer cell death: oxidative stress-independent and -dependent cytotoxic potentiation. Int J Oncol 38: 1731-1739, 2011. 
14. Chen S, Fang Y, Ma L, Liu S and Li X: Realgar-induced apoptosis and differentiation in all-trans retinoic acid (ATRA)-sensitive $\mathrm{NB}_{4}$ and ATRA-resistant $\mathrm{MR}_{2}$ cells. Int J Oncol 40: 1089-1096, 2012.

15. Li JE, Sun GL, Wu YL and Wu WL: Preliminary study on the molecular mechanism of K562 cell apoptosis induced by $\mathrm{As}_{2} \mathrm{~S}_{2}$. Zhonghua Zhong Liu Za Zhi 25: 220-224, 2003 (In Chinese).

16. Wang LW, Shi YL, Wang N, Gou BD, Zhang TL and Wang K: Association of oxidative stress with realgar-induced differentiation in human leukemia HL-60 cells. Chemotherapy 55: 460-467, 2009.

17. Wang N, Wang LW, Gou BD, Zhang TL and Wang K: Realgarinduced differentiation is associated with MAPK pathways in HL-60 cells. Cell Biol Int 32: 1497-1505, 2008.

18. Zhao XA and Liu SX: Effects of realgar on tissue factor expression of NB4 and MR2 cells. Zhongguo Zhong Yao Za Zhi 28: 553-556, 2003 (In Chinese).

19. Luo LY, Huang J, Gou BD, Zhang TL and Wang K: Induction of human promyelocytic leukemia HL-60 cell differentiation into monocytes by arsenic sulphide: involvement of serine/threonine protein phosphatases. Leuk Res 30: 1399-1405, 2006.

20. Li HM, Long Y, Qing C, et al: Arsenic trioxide induces apoptosis of Burkitt lymphoma cell lines through multiple apoptotic pathways and triggers antiangiogenesis. Oncol Res 19: 149-163, 2011.

21. Wang R, Liu C, Xia L, et al: Ethacrynic acid and a derivative enhance apoptosis in arsenic trioxide-treated myeloid leukemia and lymphoma cells: the role of glutathione S-transferase p1-1. Clin Cancer Res 18: 6690-6701, 2012.

22. Zhang Y and Nie L: Studies of apoptosis of malignant lymphoma cells induced by arsenic trioxide. Cell Biol Int 25: 1003-1006, 2001.

23. Zhou L, Jing Y, Styblo M, Chen Z and Waxman S: GlutathioneS-transferase pi inhibits $\mathrm{As}_{2} \mathrm{O}_{3}$-induced apoptosis in lymphoma cells: involvement of hydrogen peroxide catabolism. Blood 105: 1198-1203, 2005.

24. Zhang C, Huang SL, Xiang Y and Guo AX: Study on realgar inducing apoptosis in T lymphocytic cell line CEM. Zhong Xi Yi Jie He Xue Bao 1: 42-43, 2003 (In Chinese).

25. Jung HJ, Chen $\mathrm{Z}$ and McCarty N: Synergistic anticancer effects of arsenic trioxide with bortezomib in mantle cell lymphoma. Am J Hematol 87: 1057-1064, 2012.

26. Spencer SL and Sorger PK: Measuring and modeling apoptosis in single cells. Cell 144: 926-939, 2011.

27. Brunelle JK and Letai A: Control of mitochondrial apoptosis by the Bcl-2 family. J Cell Sci 122: 437-441, 2009.

28. Soriano ME and Scorrano L: The interplay between BCL-2 family proteins and mitochondrial morphology in the regulation of apoptosis. Adv Exp Med Biol 687: 97-114, 2010.

29. Chipuk JE, Moldoveanu T, Llambi F, Parsons MJ and Green DR: The BCL-2 family reunion. Mol Cell 37: 299-310, 2010.

30. Ghobrial IM, Witzig TE and Adjei AA: Targeting apoptosis pathways in cancer therapy. CA Cancer J Clin 55: 178-194, 2005.

31. Mikhailov V, Mikhailova M, Degenhardt K, Venkatachalam MA, White E and Saikumar P: Association of Bax and Bak homo-oligomers in mitochondria. Bax requirement for Bak reorganization and cytochrome $c$ release. J Biol Chem 278: 5367-5376, 2003.

32. Ariyama H, Qin B, Baba E, et al: Gefitinib, a selective EGFR tyrosine kinase inhibitor, induces apoptosis through activation of Bax in human gallbladder adenocarcinoma cells. J Cell Biochem 97: 724-734, 2006.

33. Bogner C, Schneller F, Hipp S, Ringshausen I, Peschel C and Decker T: Cycling B-CLL cells are highly susceptible to inhibition of the proteasome: involvement of p27, early D-type cyclins, Bax, and caspase-dependent and -independent pathways. Exp Hematol 31: 218-225, 2003.

34. Cao X, Deng X and May WS: Cleavage of Bax to p18 Bax accelerates stress-induced apoptosis, and a cathepsin-like protease may rapidly degrade p18 Bax. Blood 102: 2605-2614, 2003.

35. Cartron PF, Oliver L, Juin P, Meflah K and Vallette FM: The p18 truncated form of Bax behaves like a Bcl-2 homology domain 3-only protein. J Biol Chem 279: 11503-11512, 2004.

36. Choi WS, Lee EH, Chung CW, et al: Cleavage of Bax is mediated by caspase-dependent or -independent calpain activation in dopaminergic neuronal cells: protective role of $\mathrm{Bcl}-2$. J Neurochem 77: 1531-1541, 2001.

37. Decker T, Oelsner M, Kreitman RJ, et al: Induction of caspasedependent programmed cell death in B-cell chronic lymphocytic leukemia by anti-CD22 immunotoxins. Blood 103: 2718-2726, 2004.
38. Gao G and Dou QP: N-terminal cleavage of bax by calpain generates a potent proapoptotic $18-\mathrm{kDa}$ fragment that promotes Bcl-2-independent cytochrome $\mathrm{C}$ release and apoptotic cell death. J Cell Biochem 80: 53-72, 2000.

39. Hubaux R, Vandermeers F, Crisanti MC, et al: Preclinical evidence for a beneficial impact of valproate on the response of small cell lung cancer to first-line chemotherapy. Eur J Cancer 46: 1724-1734, 2010

40. Itoh M, Chiba H, Noutomi T, Takada $\mathrm{E}$ and Mizuguchi J: Cleavage of Bax- $\alpha$ and $B c l-x_{L}$ during carboplatin-mediated apoptosis in squamous cell carcinoma cell line. Oral Oncol 36: 277-285, 2000.

41. Li N, Lin P, Cai C, Pan Z, Weisleder N and Ma J: The aminoterminal peptide of Bax perturbs intracellular $\mathrm{Ca}^{2+}$ homeostasis to enhance apoptosis in prostate cancer cells. Am J Physiol Cell Physiol 296: C267-C272, 2009.

42. Sačková V, Kuliková L, Kello M, Uhrinová I and Fedoročko P: Enhanced antiproliferative and apoptotic response of HT-29 adenocarcinoma cells to combination of photoactivated hypericin and farnesyltransferase inhibitor manumycin A. Int J Mol Sci 12: 8388-8405, 2011.

43. Tavolari S, Bonafè M, Marini M, et al: Licofelone, a dual COX/5-LOX inhibitor, induces apoptosis in HCA-7 colon cancer cells through the mitochondrial pathway independently from its ability to affect the arachidonic acid cascade. Carcinogenesis 29: 371-380, 2008.

44. Thomas A, El Rouby S, Reed JC, et al: Drug-induced apoptosis in B-cell chronic lymphocytic leukemia: relationship between p53 gene mutation and bcl-2/bax proteins in drug resistance. Oncogene 12: 1055-1062, 1996.

45. Toyota H, Yanase N, Yoshimoto T, Moriyama M, Sudo T and Mizuguchi J: Calpain-induced Bax-cleavage product is a more potent inducer of apoptotic cell death than wild-type Bax. Cancer Lett 189: 221-230, 2003.

46. Wood DE and Newcomb EW: Caspase-dependent activation of calpain during drug-induced apoptosis. J Biol Chem 274: 8309-8315, 1999.

47. Wood DE and Newcomb EW: Cleavage of Bax enhances its cell death function. Exp Cell Res 256: 375-382, 2000.

48. Wood DE, Thomas A, Devi LA, et al: Bax cleavage is mediated by calpain during drug-induced apoptosis. Oncogene 17: 1069-1078, 1998.

49. Yanase N, Ohshima K, Ikegami H and Mizuguchi J: Cytochrome c release, mitochondrial membrane depolarization, caspase-3 activation, and Bax-alpha cleavage during IFN-alpha-induced apoptosis in Daudi B lymphoma cells. J Interferon Cytokine Res 20: 1121-1129, 2000.

50. Yeo JK, Cha SD, Cho CH, et al: Se-methylselenocysteine induces apoptosis through caspase activation and Bax cleavage mediated by calpain in SKOV-3 ovarian cancer cells. Cancer Lett 182: 83-92, 2002.

51. Aiyar SE, Park H, Aldo PB, et al: TMS, a chemically modified herbal derivative of resveratrol, induces cell death by targeting Bax. Breast Cancer Res Treat 124: 265-277, 2010.

52. Bellosillo B, Villamor N, López-Guillermo A, et al: Complement-mediated cell death induced by rituximab in B-cell lymphoproliferative disorders is mediated in vitro by a caspaseindependent mechanism involving the generation of reactive oxygen species. Blood 98: 2771-2777, 2001.

53. Chaudhry MA, Chodosh LA, McKenna WG and Muschel RJ: Gene expression profile of human cells irradiated in G1 and G2 phases of cell cycle. Cancer Lett 195: 221-233, 2003.

54. Lin PH, Pan Z, Zheng L, Li N, Danielpour D and Ma JJ: Overexpression of Bax sensitizes prostate cancer cells to TGF- $\beta$ induced apoptosis. Cell Res 15: 160-166, 2005.

55. Sánchez-Gómez MV, Alberdi E, Pérez-Navarro E, Alberch J and Matute C: Bax and calpain mediate excitotoxic oligodendrocyte death induced by activation of both AMPA and kainate receptors. J Neurosci 31: 2996-3006, 2011.

56. Karlsson J, Øra I, Pörn-Ares I and Påhlman S: Arsenic trioxideinduced death of neuroblastoma cells involves activation of Bax and does not require p53. Clin Cancer Res 10: 3179-3188, 2004.

57. Karlsson J, Pietras A, Beckman S, Pettersson HM, Larsson C and Påhlman S: Arsenic trioxide-induced neuroblastoma cell death is accompanied by proteolytic activation of nuclear Bax. Oncogene 26: 6150-6159, 2007.

58. Paris C, Bertoglio J and Bréard J: Lysosomal and mitochondrial pathways in miltefosine-induced apoptosis in U937 cells. Apoptosis 12: 1257-1267, 2007. 